\title{
The age and origin of the Vaasa migmatite complex revisited
}

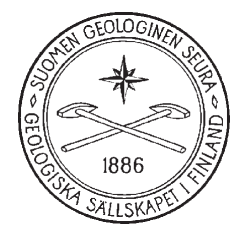

\author{
Einari SuikKanen ${ }^{1 *}$, Hannu Huhma ${ }^{2}$, Matti Kurhila ${ }^{1,2}$ \\ AND YANN LAHAYE ${ }^{2}$ \\ ${ }^{1}$ University of Helsinki, Department of Geosciences and Geography, FI-00014 University \\ of Helsinki, Finland \\ ${ }^{2}$ Geological Survey of Finland, P.O. Box 96, FI-02151, Espoo, Finland
}

\begin{abstract}
The origin of the Vaasa migmatite complex was studied by using whole-rock Sm-Nd and zircon Lu-Hf and U-Pb data in conjunction with whole-rock major and trace element geochemistry. The concordia ages of five Vaasa area granitoid samples are 1.88-1.86 $\mathrm{Ga}$, constraining the age of peak migmatization. The ages of inherited zircon cores in the samples show two clear age populations at 2.02-1.92 Ga and c. 2.7 Ga, which correspond to ages yielded by a mica schist sample from the adjacent Evijärvi belt, as well as with published values for the Evijärvi belt zircon. The initial $\varepsilon_{\mathrm{Nd}}$ values of the Vaasa complex samples are relatively unradiogenic (from -3.0 to -2.0 ). Such values are comparable to a value (-3.6) calculated for the Evijärvi mica schist, as well as to literature values (from 3.0 to -0.5) for the Evijärvi belt. The average initial zircon $\varepsilon_{\mathrm{Hf}}$ values of four of the granitoids range from -10 to -5 and are in agreement with the Nd-isotopic results, whereas the northmost sample has a significantly higher value (+1). The deviation is suggested to result from disequilibrium melting of zircon. The isotopic and geochronological data indicate that the Vaasa complex granitoids formed by partial melting of the Evijärvi belt metasedimentary rocks.
\end{abstract}

Keywords: migmatites, granites, diatexite, metatexite, Svecofennian Orogeny, partial melting, geochronology, absolute age, zircon, U/Pb, Lu/Hf, Sm/Nd, Proterozoic, Paleoproterozoic, South Ostrobothnia, Finland

* Corresponding author email: einari.suikkanen@gmail.com

\section{Introduction}

Svecofennian orogeny has attracted research for several decades. Following the first clues obtained from zircon ages in the 1960's (Kouvo and Tilton, 1966), the Lu-Hf and Sm-Nd characteristics in the 1980's (Patchett et al., 1981; Huhma, 1986), and subsequent geological and geophysical studies, the orogeny is now interpreted as a series of collisional and extensional stages that led to the accretion of 
several crustal terranes at 1.92-1.79 Ga. Models for a composite orogen have been presented and improved in several studies, including Nironen (1997), Lahtinen et al. (2005; 2009) and Korja and Heikkinen (2005). Although the research has produced a great amount of geochronological and other information, the detailed history of the orogen is still far from unraveled. However, as the orogeny is responsible for most of the bedrock geology of western and southern Finland, the continuing effort of the scientific community is set on understanding its complex tectonic setting.

One of the key pieces in the Svecofennian puzzle is the age and origin of the Vaasa migmatite complex in western Finland. The Vaasa granite, as the area is widely known (e.g., Sipilä et al., 2008), is commonly described as a metamorphic core complex. The area extends to the coast of Sweden in the west and is bordered by the Paleoproterozoic Bothnia schist belt in the north, east and south. In Finland, the central parts of the complex mostly comprise diatexite migmatites and granitoid rocks, whereas metatexite migmatites and gneisses dominate the edges. Previous studies of the area suggest that the complex formed mostly by in situ migmatization of the Bothnia belt rocks (Mäkitie, 2001; Sipilä et al., 2008) during the culmination of the Svecofennian orogeny in western Finland at 1.90-1.87 Ga (Korsman et al., 1997; Lahtinen et al., 2005). This paper builds on previous research related to the origin of the Vaasa migmatite complex using new isotopic and geochronological data.

Because of zircon's ability to survive multiple geological events, internal parts of zircon crystals often show several growth stages that can be imaged using scanning electron microscopy (SEM). The age of peak anatexis, as well as any detrital populations (e.g. Fedo et al., 2003), can be efficiently identified using in situ isotopic analyses of zircon by laser ablation-multicollector-inductively coupled plasma mass spectrometry (LA-MC-ICPMS). Because zircon is the dominant host of Hf in felsic rocks, the in situ method also allows for the utilization of the Lu-Hf system for the purposes of petrogenetic tracing (e.g., Andersen et al., 2002). We use in situ zircon $\mathrm{U}-\mathrm{Pb}$ and $\mathrm{Lu}-\mathrm{Hf}$ isotope data in conjunction with whole-rock major and trace element and Sm$\mathrm{Nd}$ isotope data to obtain insights to the age and formation of the Vaasa migmatite complex and its genetic relationship with the Bothnia schist belt.

\section{Geological Setting}

The Svecofennian domain in Finland comprises three lithologically distinct accretionary units (Korsman et al., 1997). According to Lahtinen et al. (2005) the Svecofennian orogen formed during multiple collisional, accretionary, and extensional events at 1.92-1.79 Ga. The primitive arc complex of central Finland that is situated next to the Archean Karelian craton formed early at $1.92 \mathrm{Ga}$, after which subsequent orogenic processes formed the accretionary arc complexes of central and western Finland and southern Finland (Fig. 1). Synorogenic magmatism at 1.90-1.87 Ga gave rise to several Iand A-type granitoid plutons (Nironen, 2005), as well as to mafic-ultramafic intrusions and arc-type volcanic rocks that freckle the Svecofennian domain (Peltonen, 2005). The Svecofennian granitoids are enveloped in Paleoproterozoic schist belts and together these two types comprise most of the Svecofennian bedrock.

The first plate tectonic interpretation of the Svecofennian domain by Hietanen (1975) described the Bothnian basin as an inter-arc basin that was located between the Archean Karelian craton and the so-called Svionian island arc. Although more recent tectonic models have refined the original interpretation, e.g. by introducing the idea of a composite orogen (e.g. Nironen, 1997; Lahtinen et al. 2005), the idea of a Bothnian basin has not been refuted. At 1.92-1.91 Ga the Bothnian basin next to the primitive arc complex was filled with sediment originating from Proterozoic microcontinents, the primitive arc, as well as from the Karelian craton (Lahtinen et al., 2009). In western Finland the orogeny culminated at 1.90-1.87 Ga when the arc complex of central and western Finland accreted at the edge of the primitive arc complex (Lahtinen et al., 2005). The Bothnia belt is an orogenic schist belt that formed when the sedimentary rocks of the Bothnian basin metamorphosed at 1.89-1.88 Ga 
(Kähkönen, 2005). The belt can be further divided into Evijärvi and Ylivieska belts that represent separate supracrustal successions with deposition ages of 1.92-1.91 Ga and 1.90-1.88 Ga, respectively (Lahtinen et al., 2002).

The Ylivieska belt (Fig. 1) consists of 1.90 to $1.88 \mathrm{Ga}$ arc-type volcanic rocks along with turbiditic mica schists and metaconglomerates that are surrounded by synorogenic (1.89-1.87 Ga) granitoids and mafic-ultramafic intrusions (Korsman et al., 1997). The belt is bordered by the 1.92 Ga Primitive arc complex in the north and east, the Central Finland Granitoid Complex in the south, and the Evijärvi schist belt in the west (Fig. 1). The Evijärvi belt, an area of interest in this research, consists mostly of turbiditic graywackes and mudrocks that have metamorphosed into mica gneisses and mica schists in low-pressure amphibolite facies conditions at 1.89-1.88 Ga (Kähkönen, 2005). Small bodies of metavolcanic rocks,

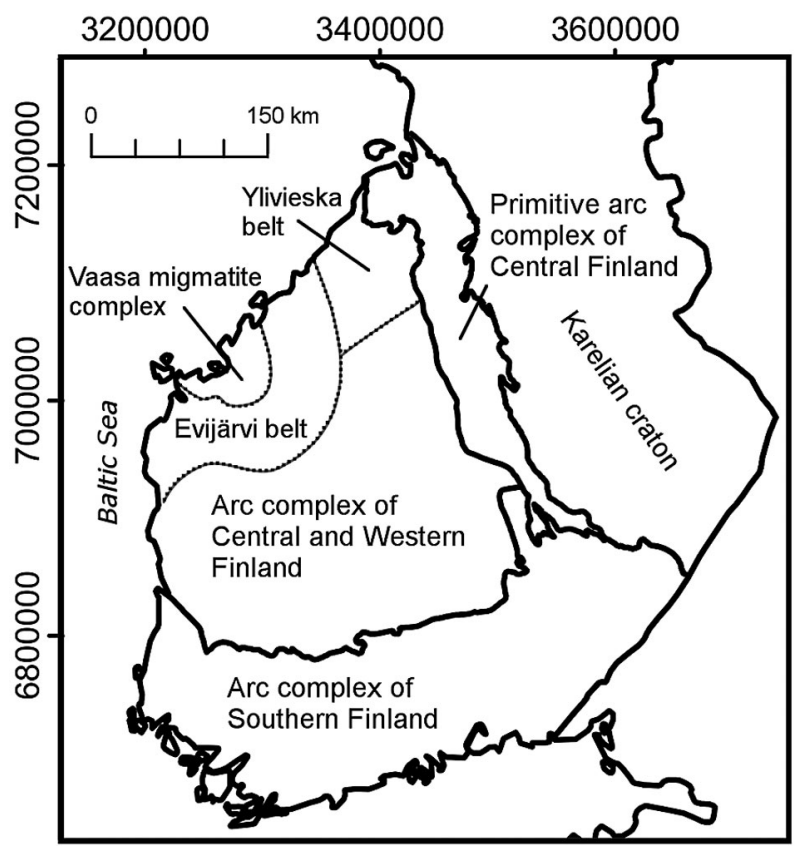

Fig. 1. The Svecofennian domain consists of three arc complexes that accreted to the Karelian craton c. 1.9 Ga. The Bothnia belt is a part of the arc complex of Central and Western Finland and comprises the Vaasa migmatite complex, the Evijärvi belt, and the Ylivieska belt. Redrawn after Korsman et al. (1997) and the 1:200k (2011) bedrock map by the Geological Survey of Finland. synorogenic granitoids and granitic pegmatites are also present (Mäkitie et al., 1999). According to Kähkönen (2005), the Evijärvi and Ylivieska belts formed as parts of the same subduction complex, the former representing the accretionary prism and the latter corresponding to a part of the volcanic arc.

Across a gradual boundary to the west of the Evijärvi belt lies the Vaasa migmatite complex (Figs. 1 and 2) that is also commonly referred to as the Vaasa granite area (e.g. Sipilä et al. 2008, and references therein). The area mostly consists of diatexite or metatexite migmatites that have formed under low-pressure amphibolite or granulite facies conditions (Sipilä et al., 2008). Pelitic and psammitic relicts are common and schlieren texture can be found in places where metatexites grade into diatexites. Porphyritic and even-grained types of leucosomes with granitic or granodioritic compositions are present. K-feldspar crystals can be up to $10 \mathrm{~cm}$ in diameter and have thus been called megacrysts by Mäkitie (2001). Garnet is a common accessory mineral, especially in the southern Vaasa migmatite complex. Pegmatites and aplitic veins are abundant in some parts of the complex and cut the diatexites horizontally and vertically. On the basis of their geochemistry, the bulk of the leucosomes match peraluminous S-type granitoids (A/CNK $>1.1$ ). Sipilä et al. (2008) drew a distinction between heterogeneous Vaasa-type and more homogeneous Vöyri-type granitoids. The former are mostly granodiorites, whereas the latter show exclusively granitic compositions in the TAS-diagram of Cox et al. (1979), and contain only a small amount of metasedimentary relicts. Sipilä et al. (2008) presented ages of monazite and zircon fractions from two localities of the Vaasa complex. They reported a monazite age of $1858 \pm 2 \mathrm{Ma}$ and a zircon age of $1878 \pm 4 \mathrm{Ma}$ for a Vöyri-type granite from Isomäki, Vöyri-Maksamaa (X=7020522, Y=3271022). A tonalite from Alanevankalliot, Kortesjärvi ( $\mathrm{X}=$ 70229107, $Y=3302004)$, yielded a monazite age of $1865 \pm 2 \mathrm{Ma}$, whereas its zircon U-Pb TIMS data were heterogeneous.

The petrographic studies of Mäkitie (2001) along the eastern border of the area at Kauhava 


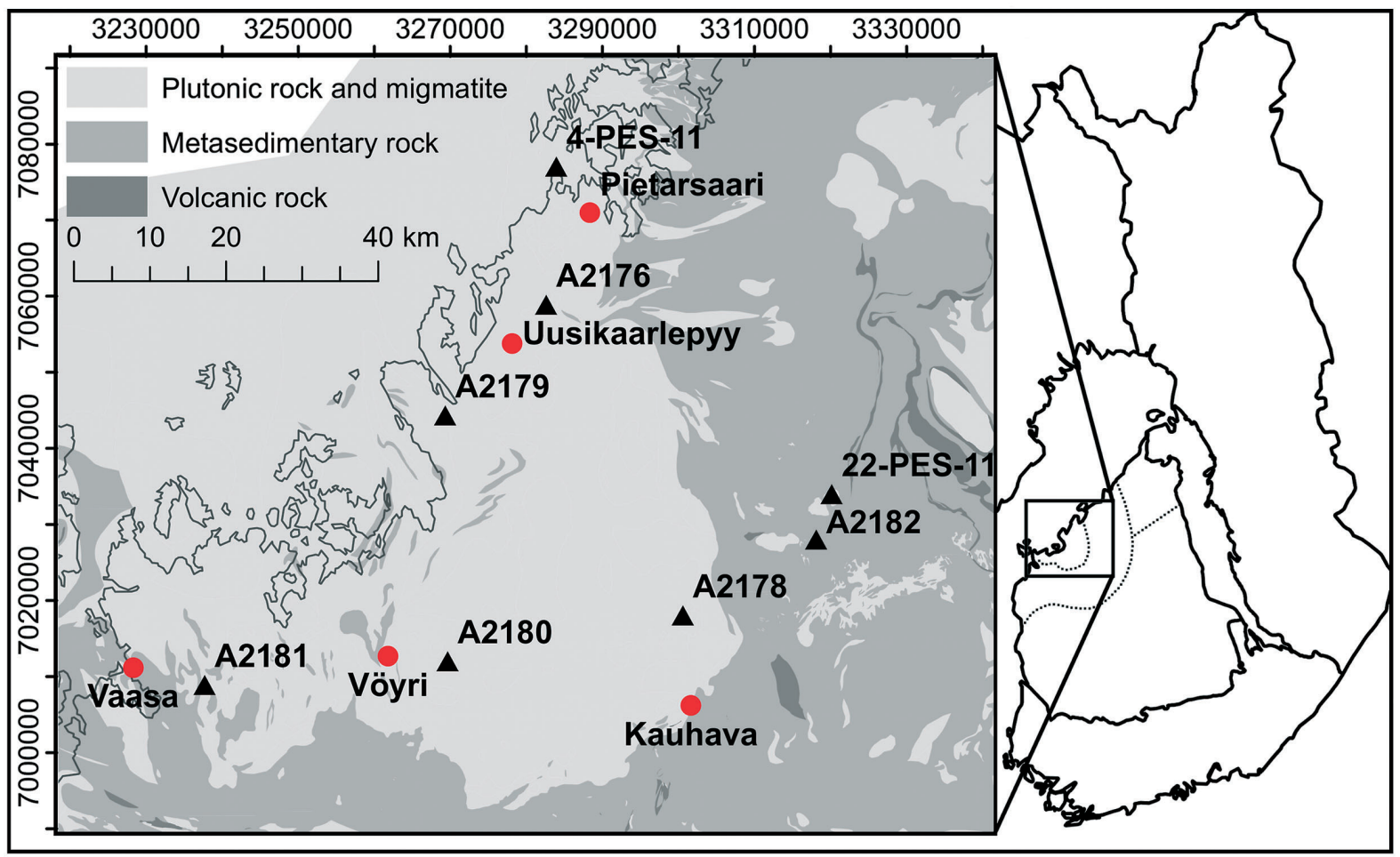

Fig. 2. A simplified lithological map of the Vaasa migmatite complex. Triangle symbols mark the samples used in this study. Redrawn after the 1:200k bedrock map (2011) by the Geological Survey of Finland.

indicate that the metatexite-diatexite transition is gradual and lacks the features of intrusive granitoids, such as ductile wall rock deformation and a chilled margin. In addition, Sipilä et al. (2008) observed that the numerous relictic inclusions have compositions that are indistinguishable from the Evijärvi belt metasedimentary rocks.

\section{Samples and analytical methods}

Field work was carried out in the fall of 2011 at the Vaasa migmatite complex and the surrounding Evijärvi belt. Five of the granitoid samples from the Vaasa complex (A2176, A2178-A2181) along with one sample that represents a typical Evijärvi mica schist (A2182) were analyzed for their isotopic and chemical compositions. Samples 4-PES-11 and 22PES-11 were included in the geochemical analyses. The petrographic features of the samples were studied from thin sections, hand-samples, and SEM images. They are summarized in the following sections.

\section{A2176}

Soklothedet, Uusikaarlepyy (X=7058289,

$\mathrm{Y}=3282692$ )

Sample A2176 is the northmost sample that was included in the isotopic studies. It is a granodioritic diatexite leucosome and has $10 \%$ biotite. Zircon is present as rounded, longish grains. Some zircon grains have visible overgrowth. No distinct zircon cores are present.

\section{A2178}

Susivuori, Kauhava (X=7017496, $\mathrm{Y}=3300670)$

Sample A2178 is from the southeastern boundary of the Vaasa complex. It is a granodioritic diatexite leucosome with $20 \%$ biotite and abundant Kfeldspar megacrysts. It has mostly prismatic, longish zircon. Cores are rare and/or hard to recognize. 


\section{A2179}

Brinksbacken, Uusikaarlepyy (X=7043744, $\mathrm{Y}=3269419)$

Sample A2179 is from the western Vaasa complex. It is a granitic diatexite leucosome with $25 \%$ biotite and a gneissic texture. K-feldspar megacrysts are voluminous and accessory garnet is present in the sample. Zircon grains are mostly rounded and have cores that are easy to distinguish due to their low brightness in BSE images.

\section{A2180}

Kalomskogen, Vöyri $(\mathrm{X}=7011437, \mathrm{Y}=3269769)$

Sample A2180 is a leucocratic granite with $5 \%$ biotite and a gneissic texture. No metasedimentary inclusions or strata were seen at the sample site, as in the case for Vöyri-type granitoids. The sample has mostly large rounded zircon grains. Some prismatic grains are also present. Distinct inherited cores are common in the sample zircon.

\section{A2181}

Gåtakärskogen, Vaasa (X=7008353, Y=3237845)

The southernmost sample that was included in the analyses. It is a granodioritic diatexite leucosome with $15 \%$ biotite. A2181 has the greatest amount of garnet $(-5-10 \%)$ and K-feldspar megacrysts. The zircon grains are rounded or prismatic, longish, and some have distinct cores.

\section{A2182}

Laukkonen, Evijärvi (X=7027450, Y=3318252)

Sample A2182 is a mica schist that was collected to represent a typical metasedimentary rock of the Evijärvi belt. Zircon is present as rounded grains of different shapes and sizes.

\section{4-PES-11 and 22-PES-11}

Fiskhamn, Pietarsaari (X=7076464, Y=3284050) and Kalliokangas, Evijärvi (X=7018595,

$\mathrm{Y}=3227862$ )

Two additional samples were included in the major and trace element analyses. 4-PES-11 is a granidioritic leucosome of a schlieren-textured metatexite from Pietarsaari and 22-PES-11 is an intrusive granodiorite from the Evijärvi belt. No metasedimentary inclusions were seen at the sample site of 22-PES-11.

\subsection{Lu-Hf and U-Pb isotope analysis}

The selected samples were ground to a grain size of $<350 \mu \mathrm{m}$ using a jaw crusher and a small swing mill at the University of Helsinki. Because a swing mill is usually used to make finely powdered rock samples, and is very effective, only the outer grindstone was used and the run times were kept around thirty seconds, before the particles that included the zircon grains were sieved out. Fine dust was carefully washed off, and the samples were dried before heavy liquid separation with methylene iodide $(\rho=3.3 \mathrm{~g} / \mathrm{mL})$ and Clerici solution $(\rho=3.8 \mathrm{~g} /$ $\mathrm{mL}$ ). Magnetic minerals were then removed using a hand magnet and a Frantz magnetic separator to obtain clean zircon samples. Approximately 60 zircon grains were hand-picked from each sample to ensure a representative take, and the selected grains were mounted in epoxy and polished to expose their interiors for analysis.

The internal structures of the zircon grains were studied by the use of SEM imaging. Both cathodoluminescence and backscattered electron images were taken for distinguishing different growth zones, as well as fractures, inclusions, and other impurities. The images were then used to pick suitable spots for the LA-MC-ICPMS analyses. In the case of zircon samples from granitoids, distinct growth zones were analyzed when possible. Different zircon age populations were identified from the metasedimentary Evijärvi belt sample, and five or more Hf analyses were done for each population when possible.

A Nu Plasma HR MC-ICP mass spectrometer with a Photon Machine Analyte G2 laser microprobe was used to measure isotope values for both $\mathrm{U}-\mathrm{Pb}$ and Lu-Hf systems in situ at the Finnish Isotope Geosciences Laboratory, Geological Survey of Finland, Espoo. Depending on the elements of interest and their concentrations, different settings for the ablation must be used to obtain required sensitivity and precision. For U-Pb, a static ablation mode was used, the beam size was set to $20 \mu \mathrm{m}$, pulse frequency was $5 \mathrm{~Hz}$ and the beam energy 
density was $0.55 \mathrm{~J} / \mathrm{cm}^{2}$. The ablation was done in He gas within a HelEx ablation cell. The He aerosol was mixed with Ar before it was driven into the plasma. A configuration of three secondary electron multipliers (for masses of 204, 206 and 207) and one Faraday cup (for 238) was used to detect the ions. ${ }^{235} \mathrm{U}$ was calculated by the use of a natural ${ }^{238} \mathrm{U} /{ }^{235} \mathrm{U}$ value of 137.88 . The measurement times were $30 \mathrm{~s}$ for background and $60 \mathrm{~s}$ for ablation. The He supply adds some ${ }^{204} \mathrm{Hg}$ to the plasma, which is corrected by on-mass background measurement prior to each analysis. Common lead $\left({ }^{204} \mathrm{~Pb}\right)$ correction has to be made on the basis of the background measurement. The calculated ${ }^{207} \mathrm{~Pb} /$ ${ }^{206} \mathrm{~Pb}$ age is also used to correct for the common lead contribution based on the common-lead model of Stacey and Kramers (1975) whenever the signal rises above the detection limit. Two zircon standards (GJ1, age $609 \pm 1 \mathrm{Ma}$, and an in-house standard A1772, age 2712 $\pm 1 \mathrm{Ma}$ (Huhma et al., 2012a)) were used to correct the raw data for the background, laser-induced fractionation, instrumental mass discrimination, and drift in ion counter gain. Calculations were done with an interactive spreadsheet program written by Tom Andersen for MS Excel in VBA (Rosa et al., 2009). Isoplot v3.71 add-in for MS Excel 2003 (Ludwig, 2008) was used for data reduction.

In order to achieve adequate precision, the signal intensity of $\mathrm{Hf}$ has to be increased relative to that of the U-Pb system. Because the amount of ablated material is much greater than with $\mathrm{U}-\mathrm{Pb}$, the $\mathrm{Hf}$ analyses should be done after $\mathrm{U}-\mathrm{Pb}$ and care should be taken not to ablate through a growth zone to a different one or to the epoxy. Since there are no problems similar to the common lead, cracks or impurities have no significant impact on the results, as long as the analysis points are confined to homogeneous growth zones. A beam size of $50 \mu \mathrm{m}$ and a beam energy density of $2.8 \mathrm{~J} / \mathrm{cm}^{2}$ were used. A setting of 6 Faraday detectors was used for masses ${ }^{173} \mathrm{Yb},{ }^{175} \mathrm{Lu},{ }^{176} \mathrm{Hf}-\mathrm{Lu}-\mathrm{Yb},{ }^{177} \mathrm{Hf},{ }^{178} \mathrm{Hf}$, and ${ }^{179} \mathrm{Hf}$. Several correctional calculations were made for raw Hf data. The data was first filtered at $2 \sigma$ and corrected for mass discrimination using the value ${ }^{179} \mathrm{Hf} /{ }^{177} \mathrm{Hf}=0.7325$ (Patchett et al., 1981). The interferences caused by ${ }^{176} \mathrm{Yb}$ and ${ }^{176} \mathrm{Lu}$ were corrected with the values ${ }^{176} \mathrm{Yb} /{ }^{173} \mathrm{Yb}=0.796218$ (Chu et al. 2002) and ${ }^{176} \mathrm{Lu} /{ }^{175} \mathrm{Lu}=0.02656$ (Scherer et al., 2001), respectively. For calculations, a value of $1.867 \cdot 10^{-11} \mathrm{a}^{-1}$ for the decay constant of ${ }^{176} \mathrm{Lu}$ was used (Scherer et al. 2001), along with the presentday chondritic values of ${ }^{176} \mathrm{Lu} /{ }^{177} \mathrm{Hf}=0.0336$ and ${ }^{176} \mathrm{Hf} /{ }^{177} \mathrm{Hf}=0.282785$ (Bouvier et al., 2008). Reference zircon GJ1 and in-house standard A2024 were run as unknowns at frequent intervals. ${ }^{176} \mathrm{Hf} /$ ${ }^{177} \mathrm{Hf}$ values of $0.28204 \pm 4(1 \sigma, \mathrm{n}=32)$ and 0.28171 $\pm 4(1 \sigma, \mathrm{n}=22)$ were measured for GJ1 and A2024, respectively. The GJ1 value is within error to results obtained by solution MC-ICP-MS analyses (0.281998 \pm 7 , Gerdes and Zeh, 2006; 0.282000 \pm 5 , Morel et al., 2008). The in-house standard A2024 has not been analyzed by solution and is characterized by a variation in $176 \mathrm{Yb} / 177 \mathrm{Hf}$ (up to 0.088 ), which is within the range of the unknown (up to 0.066). A2024 is therefore useful in controlling the quality of the $\mathrm{Yb}$ and Lu corrections because of a good external reproducibility, similar to GJ1, and a lack of correlation between the level of $\mathrm{Yb}$ interferences and the Hf isotopic composition.

\subsection{Sm-Nd isotope analysis}

$\mathrm{Sm}-\mathrm{Nd}$ isotope analyses were made from whole-rock powders using thermal ionization mass spectrometry in conjunction with isotope dilution. Whole-rock powders were made from the hand samples using a jaw crusher and a tungsten carbide ball mill at the University of Helsinki. The separation of Sm and $\mathrm{Nd}$, and isotopic analyses followed the methods described in Huhma et al. (2012b). The La Jolla standard for ${ }^{143} \mathrm{Nd} /{ }^{144} \mathrm{Nd}$ has a long-term average ratio of $0.511850 \pm 10$ at the Geological Survey of Finland. The $\varepsilon_{\mathrm{Nd}}(\mathrm{t})$ values were calculated assuming chondritic present-day values of ${ }^{143} \mathrm{Nd} /{ }^{144} \mathrm{Nd}=$ 0.51264 and ${ }^{147} \mathrm{Sm} /{ }^{144} \mathrm{Nd}=0.1966$ (Jacobsen and Wasserburg, 1980).

\subsection{Major and trace element analysis}

Whole-rock geochemical analyses of the samples were outsourced to Acme Analytical Laboratories 
Ltd. in Vancouver, Canada. Acme Analytical Labs uses a lithium metaborate-tetraborate fusion and dilute nitric digestion to prepare the sample from $200 \mathrm{mg}$ of powder. The abundances of major oxides and some trace elements were obtained by the use of ICP emission spectrometry, and the REE were determined by ICP mass spectrometry. Duplicate samples and reference materials are analyzed to control the accuracy and precision of analysis, and minimum detection limits are obtained by using preparation blanks (quartz) and reagent blanks to measure the background contamination.

\section{Results}

\subsection{Isotope geochemistry}

Results of the U-Pb analyses are given in Electronic Appendix A and presented in Fig. 3. The large magmatic zircon populations in Vaasa complex
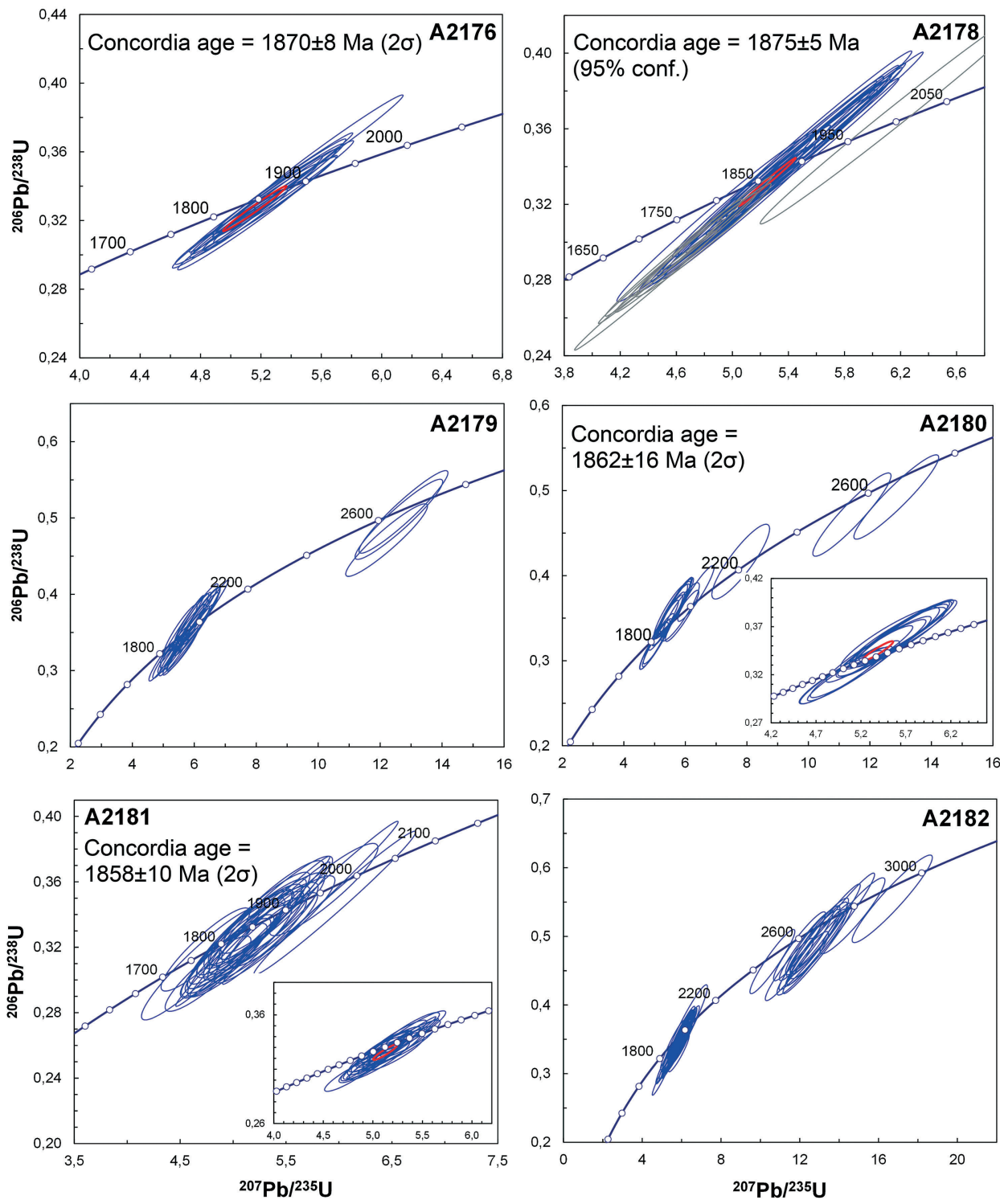

Fig. 3. U-Pb concordia diagrams for the samples. Granitoid samples 2176-A2181 are from the Vaasa migmatite complex and the mica schist sample A2182 is from the Evijärvi belt. Concordia ages have been calculated for magmatic populations where applicable. 
samples A2176, A2178, A2180, and A2181 yielded concordia ages of 1.88-1.86 Ga. Zircons in sample A2179 from the Vaasa complex consist of inherited 2.02-1.92 Ga and 2.73-2.67 Ga cores with magmatic or metamorphic rims that were mostly too thin to be analyzed. Four of the rims yielded concordant ages of 1.90-1.86 Ga. Inherited zircon was also present in samples A2178 (1.98 Ga), A2180 (1.98-1.93, 2.17 and 2.74-2.61 Ga), and A2181 $(2.02-1.92 \mathrm{Ga})$. The Evijärvi mica schist sample A2182 had detrital zircon populations with ages around 2.0-1.92 and 2.7 Ga. The inherited populations in the Vaasa complex samples are compared to the zircon populations of the Evijärvi sample A2182 in Fig. 4.

The results of the $\mathrm{Nd}$-isotopic analyses are shown in Table 1 . The elemental concentrations of Sm and Nd show substantial variation (4-22 and $16-135$ ppm, respectively), as do the ${ }^{147} \mathrm{Sm} /{ }^{144} \mathrm{Nd}$ values $(0.0982-0.1423)$. However, the initial $\varepsilon_{\mathrm{Nd}}$ values of the samples are very similar and range from -3.0 to -2.0 for the Vaasa migmatite complex granitoids. These values are close to the $\varepsilon_{\mathrm{Nd}}(\mathrm{t})$ value $(-3.6$ at $1.90 \mathrm{Ga})$ of the Evijärvi mica schist. The depleted mantle model ages calculated using the mantle evolution model of DePaolo (1981) range from 2.56 to $2.27 \mathrm{Ga}$.

The results of the Lu-Hf analyses are given in Electronic Appendix B and Table 1. The average $\varepsilon_{\mathrm{Hf}}(\mathrm{t})$ values of the Vaasa complex samples range from -10 to +1 (at $1.88-1.86 \mathrm{Ga})$. The average $\varepsilon_{\mathrm{Hf}}(\mathrm{t})$ value of the mica schist sample A2182 zircon is -14

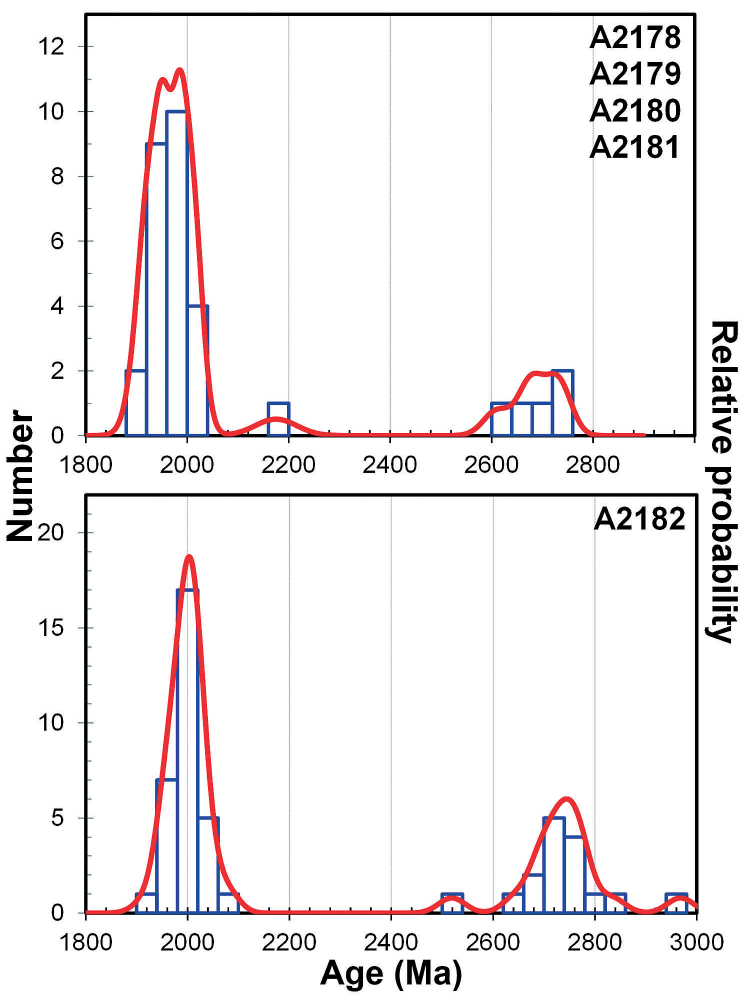

Fig. 4. Concordant ${ }^{207} \mathrm{~Pb} /{ }^{206} \mathrm{~Pb}$ ages of $>1.89 \mathrm{Ga}$ zircon in the Vaasa complex samples are compared to Evijärvi mica schist sample (A2182) zircon.

(at $1.9 \mathrm{Ga})$. Ranges of zircon $\varepsilon_{\mathrm{Hf}}(\mathrm{t})$ values for specific samples are: A2176, from -5 to +4; A2178, from -10 to $0 ; \mathrm{A} 2179$, from -30 to +3 ; $\mathrm{A} 2180$, from -17 to 0 ; A2181, from -15 to -3 ; A2182, from -31 to 0 . Detrital (sample A2182) and inherited (Vaasa complex samples) zircons have mostly negative initial $\varepsilon_{\mathrm{Hf}}$ values (Fig. 5).

Table 1. Data from the Sm-Nd TIMS analyses. Also shown are the averages and ranges of $\varepsilon \mathrm{Hf}$ values (at 1.90-1.86 Ga as per the ages reported in the table) for zircon in the samples.

\begin{tabular}{|c|c|c|c|c|c|c|c|c|c|}
\hline Sample & $\begin{array}{l}\text { Sm } \\
\text { Ppm }\end{array}$ & $\begin{array}{l}\text { Nd } \\
\text { ppm }\end{array}$ & $\begin{array}{l}{ }^{147} \mathrm{Sm} /{ }^{144} \mathrm{Nd} \\
\pm 0.4 \%\end{array}$ & $\begin{array}{l}{ }^{143} \mathrm{Nd} /{ }^{144} \mathrm{Nd} \\
\pm 2 \mathrm{SE}\end{array}$ & $\begin{array}{l}\text { Age (t) } \\
\mathrm{Ga}\end{array}$ & $\varepsilon_{N d}(t)$ & $\begin{array}{l}\mathrm{T}_{\mathrm{DM}}(\mathrm{Nd}) \\
\mathrm{Ga}\end{array}$ & $\varepsilon_{H f}(t)^{\prime}$ & range $\varepsilon_{H f}(t)$ \\
\hline A2176 & 3.77 & 19.63 & $0.1160 \pm 5$ & $0.511545 \pm 10$ & 1.87 & -2.0 & 2.33 & +0.6 & from -5 to 4 \\
\hline A2178 & 21.94 & 135.02 & $0.0982 \pm 4$ & $0.511322 \pm 10$ & 1.87 & -2.1 & 2.27 & -5.2 & from -10 to 0 \\
\hline A2179 & 6.99 & 34.41 & $0.1228 \pm 5$ & $0.511572 \pm 10$ & 1.88 & -3.0 & 2.47 & -10.2 & from -30 to 3 \\
\hline A2180 & 3.80 & 16.16 & $0.1423 \pm 6$ & $0.511849 \pm 10$ & 1.86 & -2.5 & 2.56 & -6.8 & from -17 to $5^{2}$ \\
\hline A218I & 12.10 & 71.09 & $0.1029 \pm 4$ & $0.511376 \pm 10$ & 1.86 & -2.3 & 2.29 & -7.3 & from -15 to -3 \\
\hline A2182 & 5.80 & 31.33 & $0.1118 \pm 4$ & $0.511395 \pm 10$ & 1.90 & -3.6 & 2.47 & -14.0 & from -33 to 0 \\
\hline
\end{tabular}

${ }^{1} 2 \sigma$ of zircon standard GJ1 is 3 units $(n=32)$.

${ }^{2}$ Only one positive value $(5.1, n=16)$ 


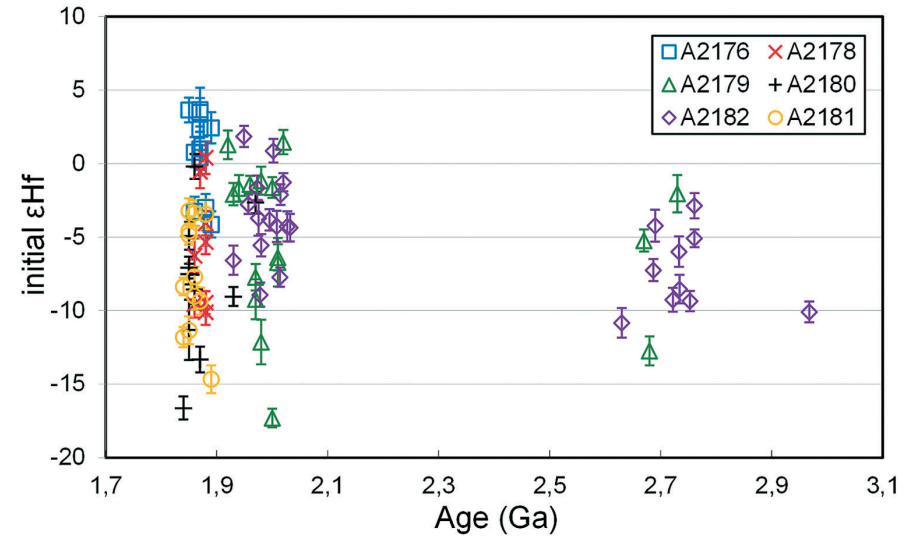

Fig. 5. The initial $\varepsilon_{\mathrm{Hf}}$ values of the dated zircons in the samples. The error bars are $2 \sigma$.

\subsection{Major and trace element geochemistry}

Table 2. Results of the whole-rock geochemical analyses for the samples used in this study.

\begin{tabular}{|c|c|c|c|c|c|c|c|c|c|c|}
\hline Sample & $A 2176$ & A2178 & A2179 & $\mathrm{A} 2180$ & A2 181 & $A 2182$ & 4-PES-II & 22-PES-II & SO- $18^{\prime}$ & $\mathrm{SO}-18^{2}$ \\
\hline \multicolumn{11}{|c|}{ Oxides (wt.\%) } \\
\hline $\mathrm{SiO}_{2}$ & 72.71 & 69.68 & 66.14 & 69.27 & 63.99 & 68.15 & 64.77 & 67.80 & 57.93 & 58.47 \\
\hline $\mathrm{Al}_{2} \mathrm{O}_{3}$ & 14.83 & 13.86 & 15.38 & 15.94 & 15.90 & 14.02 & 15.45 & 15.84 & 14.19 & 14.23 \\
\hline $\mathrm{Fe}_{2} \mathrm{O}_{3}$ & 1.84 & 4.01 & 5.55 & 2.20 & 7.18 & 5.34 & 5.69 & 3.42 & 7.63 & 7.67 \\
\hline $\mathrm{MgO}$ & 0.73 & 1.78 & 2.13 & 1.00 & 2.39 & $2.4 I$ & 2.25 & 1.53 & 3.38 & 3.35 \\
\hline $\mathrm{CaO}$ & 2.74 & 1.97 & 1.69 & 1.98 & 2.64 & 2.00 & 2.78 & 3.21 & 6.36 & 6.42 \\
\hline $\mathrm{Na}_{2} \mathrm{O}$ & 4.39 & 2.55 & 2.74 & 3.33 & 2.77 & 2.98 & 2.84 & 4.78 & 3.71 & 3.71 \\
\hline $\mathrm{K}_{2} \mathrm{O}$ & 1.78 & 4.06 & 4.35 & 4.64 & 3.19 & 3.04 & 3.83 & 1.85 & 2.16 & 2.17 \\
\hline $\mathrm{TiO} 2$ & 0.28 & 0.72 & 0.61 & 0.30 & 0.77 & 0.61 & 0.95 & 0.39 & 0.70 & 0.69 \\
\hline $\mathrm{P}_{2} \mathrm{O}_{5}$ & 0.12 & 0.08 & 0.13 & 0.22 & 0.07 & 0.15 & 0.30 & 0.09 & 0.83 & 0.83 \\
\hline $\mathrm{MnO}$ & 0.02 & 0.03 & 0.11 & 0.02 & 0.13 & 0.07 & 0.06 & 0.05 & 0.41 & 0.39 \\
\hline $\mathrm{Cr}_{2} \mathrm{O}_{3}$ & b.d.l. ${ }^{3}$ & 0.006 & 0.012 & 0.003 & 0.011 & 0.012 & 0.009 & 0.005 & 0.56 & 0.55 \\
\hline Tot. & 99.88 & 99.70 & 99.79 & 99.85 & 99.71 & 99.76 & 99.71 & 99.83 & 99.74 & 99.77 \\
\hline \multicolumn{11}{|c|}{ REE (ppm) } \\
\hline $\mathrm{La}$ & 24.8 & 147.9 & 34.5 & 15.4 & 82.7 & 38.9 & 48.3 & 13.1 & 12.2 & 12.3 \\
\hline $\mathrm{Ce}$ & 48.0 & 303.4 & 70.5 & 29.6 & 164.4 & 75.8 & 92.7 & 22.1 & 26.3 & 27.1 \\
\hline $\operatorname{Pr}$ & 5.4 & 36.3 & 8.0 & 3.5 & 18.7 & 8.6 & 10.9 & 2.7 & 3.3 & 3.5 \\
\hline $\mathrm{Nd}$ & 19.6 & 139.0 & 30.3 & 14.4 & 69.3 & 31.4 & 44.7 & 10.5 & 13.2 & 14.0 \\
\hline Sm & 34.0 & 21.7 & 6.2 & 3.1 & 11.8 & 5.7 & 7.3 & 2.1 & 2.9 & 3.0 \\
\hline $\mathrm{Eu}$ & 0.6 & 1.2 & 1.03 & 0.6 & 1.3 & 1.2 & 1.6 & 0.7 & 0.9 & 0.9 \\
\hline Gd & 2.9 & 15.0 & 5.1 & 3.0 & 10.0 & 4.9 & 5.9 & 1.7 & 3.0 & 2.9 \\
\hline Tb & 0.3 & 1.6 & 0.7 & 0.5 & 1.7 & 0.7 & 0.7 & 0.2 & 0.5 & 0.5 \\
\hline Dy & 1.3 & 7.4 & 3.6 & 2.8 & 13.1 & 4.2 & 3.4 & 1.4 & 3.0 & 3.0 \\
\hline Ho & 0.2 & 1.2 & 0.7 & 0.4 & 3.1 & 0.8 & 0.6 & 0.3 & 0.6 & 0.6 \\
\hline $\mathrm{Er}$ & 0.4 & 3.0 & 2.15 & 0.9 & 9.9 & 2.1 & 1.6 & 0.8 & 1.9 & 1.8 \\
\hline Tm & 0.03 & 0.4 & 0.3 & 0.1 & 1.4 & 0.3 & 0.2 & 0.1 & 0.3 & 0.3 \\
\hline $\mathrm{Yb}$ & 0.4 & 2.6 & 2.5 & 0.8 & 8.4 & 2.4 & 1.9 & 0.8 & 1.8 & 1.8 \\
\hline Lu & 0.03 & 0.4 & 0.4 & 0.1 & 1.3 & 0.3 & 0.2 & 0.1 & 0.6 & 0.3 \\
\hline $\mathrm{Hf}$ & 4.5 & 5.9 & 5.3 & 2.6 & 7.0 & 5.2 & 6.5 & 3.3 & 9.3 & 9.8 \\
\hline
\end{tabular}

'Reference sample (average, $n=2$ ).

${ }^{2}$ Expected values for SO-I8 obtained from Acme Laboratories Ltd.

${ }^{3}$ b.d.I $=$ below detection limit. 
Geochemical data for the studied samples are presented in Table 2. Based on duplicate analyses of sample MK19 (not from this study) and standard SO-18 the accuracy and precision of analysis are within $3 \%$ for major oxides and in general within $10 \%$ for trace elements. Fig. 6 shows the aluminum saturation indices for these samples plotted against their $\mathrm{SiO}_{2}$ contents. Sample 22-PES-11 has an A/ CNK value of $\sim 1$. Sample A2176 has a value of -1.05, whereas the other Vaasa samples have values of over 1.1. Samples A2176, A2178 and A2180 have higher $\mathrm{SiO}_{2}$ contents than the Evijärvi sample A2182, whereas samples A2181 and A2179 are less felsic than A2182.

A chondrite-normalized (McDonough and Sun, 1995) rare-earth element (REE) diagram (Fig. 7) shows a negative Eu-anomaly in all of the Vaasa migmatite complex samples, as well as in the Evijärvi mica schist, but not in sample 22-PES-11. Sample

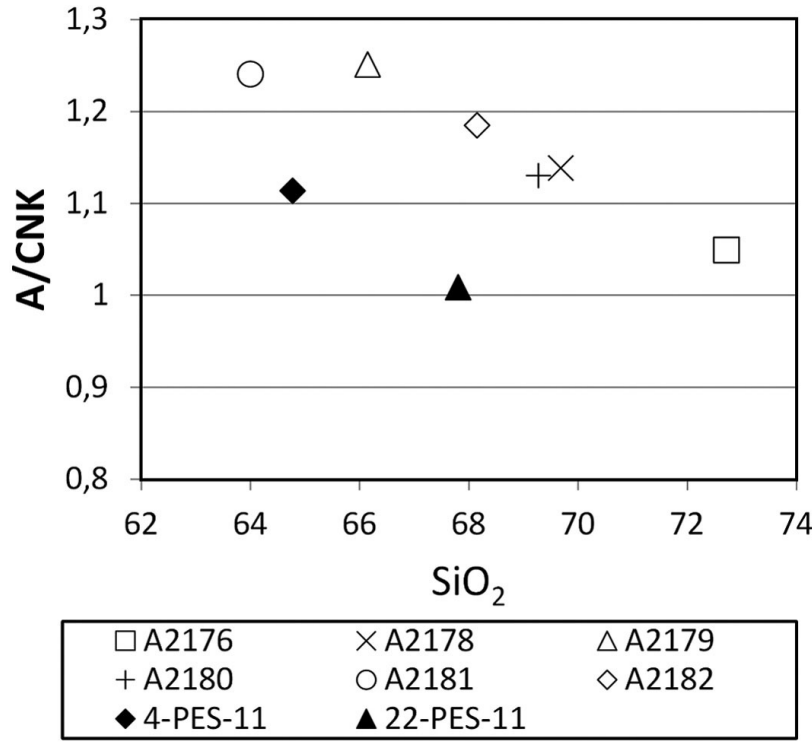

Fig. 6. Aluminum saturation index of the samples plotted against $\mathrm{SiO}_{2}$.

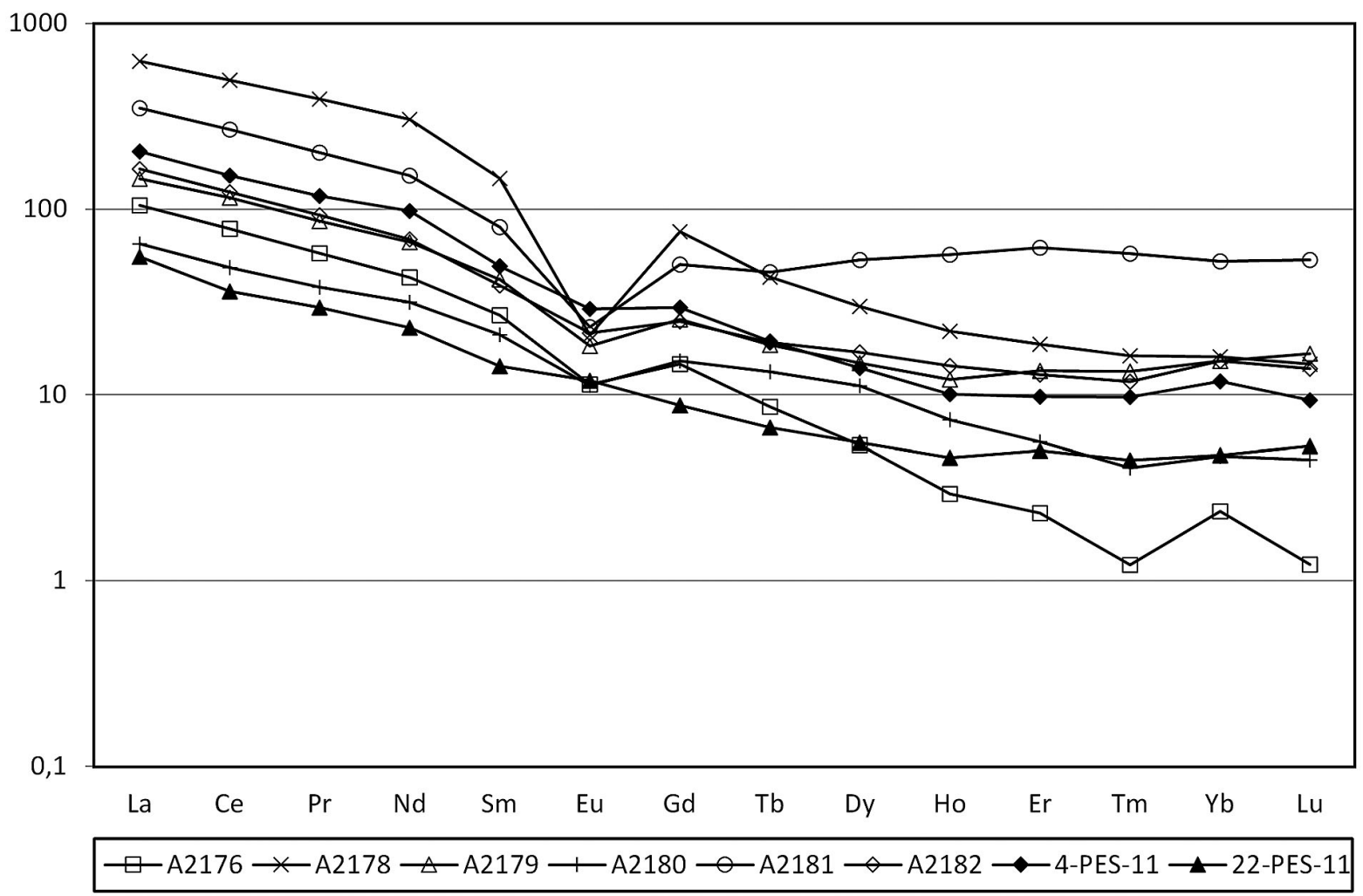

Fig. 7. A chondrite-normalized REE diagram for the samples. Normalization was done using the composition of C1 carbonaceous chondrite from McDonough and Sun (1995). 
A2176 is depleted in heavy REE (HREE) relative to other samples to the point of having a nearchondritic HREE composition, whereas sample A2181 is relatively enriched in HREE.

\section{Discussion}

\subsection{Ages}

The U-Pb age results for the metasedimentary rocks of the Evijärvi belt presented by Lahtinen et al. (2002) show a deposition age of 1.92-1.91 Ga and dominant zircon populations at 2.02-1.92 Ga and around $2.7 \mathrm{Ga}$. In this study, similar zircon age populations were observed in the Evijärvi belt mica schist, as well as in the inherited cores found in the Vaasa migmatite complex samples A2179, A2180 and A2181 (Fig. 4). The overall similarity between the zircon populations of the granitoid samples and the mica schist suggests that the former was generated by partial melting of the metasedimentary rocks of the Evijärvi belt. The source of the c. $2 \mathrm{Ga}$ zircons found in Svecofennian metasedimentary rocks is an open question raised by numerous studies (e.g. Huhma et al., 1991; Claesson et al., 1993; Lahtinen et al., 2002; Vaasjoki et al., 2003). Lahtinen et al. (2005; 2009) suggested that currently unexposed 2.1-2.0 Ga Keitele microcontinent could have been involved in the Svecofennian orogeny in western and central Finland, being a possible source for these zircons. The bulk of the Archean detritus has most likely been derived from the Karelian craton and the adjacent c. $1.92 \mathrm{Ga}$ Savo arc is a probable source for the $<1.93 \mathrm{Ga}$ detrital zircons (cf. Lahtinen et al., 2009). 2.6-2.1 Ga zircon is considered rare in Svecofennian metasedimentary rocks (Claesson et al. 1993; Lahtinen et al., 2002), which is also the case in the present study, as only two cores within this age range were found.

The concordia ages of magmatic zircons in samples A2176, A2178, A2180 and A2181 are 1.88-1.86 Ga. These ages are comparable to a monazite age from Kauhava $(1.86 \mathrm{Ga})$ reported by Sipilä et al. (2008). Although theories on the Paleoproterozoic tectonic evolution of the Finnish Svecofennian have been presented in many papers (e.g., Mäkitie, 1999; Lahtinen et al. 2005), it is not certain whether the age of peak anatexis in the Vaasa complex corresponds with an extensional or a compressional stage. Both could initiate a scenario where mantle upwelling would provide the necessary heat for the formation of the complex (Brown, 2008).

\subsection{Sm-Nd and Lu-Hf isotopes}

The initial $\varepsilon_{\mathrm{Hf}}$ values of the inherited zircon cores from samples A2179 and A2180 are mostly similar to those of the Evijärvi belt sample, and depict the contribution of a mixture of juvenile and enriched material from the Proterozoic eon (Fig. 5). Archean detrital zircons in the samples have exclusively unradiogenic compositions even in the oldest of grains and have been derived from reworked crustal material.

The initial $\varepsilon_{\mathrm{Nd}}$ values of the samples are quite coherent (from -3 to -2 ) throughout the Vaasa migmatite complex and close to the value for the Evijärvi belt sample (-3.6 at $1.90 \mathrm{Ga})$. In comparison, the granodioritic intrusive rocks of the Bothnia belt have initial $\varepsilon_{\mathrm{Nd}}$ values of around +3 (Lahtinen and Huhma, 1997), whereas published values for the Evijärvi belt range from -3 to -0.5 (at $1.90 \mathrm{Ga})$ (Huhma, 1987; Lahtinen et al., 2002). The values presented in our study have less radiogenic $\mathrm{Nd}$ isotopic compositions than felsic igneous rocks in the Svecofennian domain (Huhma et al., 2011), so the input of enriched material has indeed been extensive.

The average $\varepsilon_{\mathrm{Hf}}(\mathrm{t})$ values of zircon show variation that exceeds analytical uncertainty. Samples A2178, A2179, A2180, A2181 have subchondritic average $\mathrm{Hf}$-isotopic ratios calculated at their respective $\mathrm{U}-\mathrm{Pb}$ ages $\left(\varepsilon_{\mathrm{Hf}}(1.88-1.86 \mathrm{Ga})\right.$ from -10 to -5$)$. The Evijärvi mica schist (A2182) has even more unradiogenic zircon (average $\varepsilon_{\mathrm{Hf}}-14$ at 1.90 $\mathrm{Ga}$ ), whereas the northernmost sample A2176 shows a near-chondritic average value $(+1$ at 1.87 $\mathrm{Ga})$. The data of Vervoort et al. (1999) show that active margin sediments have in general more radiogenic Hf-isotopic compositions than passive margin sediments because of the input of arc-related 
volcaniclastic material. The observed Hf-isotopic variation could thus indicate that the input of material originating from the volcanic rocks of the Ylivieska arc and the Evijärvi area (Kähkönen, 2005; Lahtinen et al., 2009) has decreased towards southsouthwest in the Vaasa migmatite complex. However, the fact that this is not indicated by the $\mathrm{Nd}$ isotopic compositions shows that the comparison between zircon $\mathrm{Hf}$ and whole-rock $\mathrm{Nd}$ isotopes is not straightforward. Other source-related explanations exist, mainly that the sources of the Vaasa complex migmatites are representative of different parts of a turbidite succession. The amount of detrital zircons must be far greater in sands than in silts, whereas such sedimentary sorting does not significantly concern $\mathrm{Nd}$ isotopes (Vervoort et al. 1999). A recent study by Tang et al. (2014) suggests that the mixing of juvenile and enriched material at the source may not be the most important mechanism in producing Hf isotopic heterogeneities in anatectic granites. Whenever an anatectic melt does not reach isotopic equilibrium with the protolith, the melt may not fully represent the source. The release of Hf is controlled by dissolution of zircon, and thus a significant amount of ${ }^{177} \mathrm{Hf}$ will be retained in the residual whenever zircon dissolution is hindered, such as in rapidly melting or high $\mathrm{Zr}$ systems. In such cases the release of Hf from zircon and other sources is decoupled, which may lead to significant variation in the $\varepsilon_{\mathrm{Hf}}$ values of newly formed magmatic zircon, and cause the decoupling of $\varepsilon_{\mathrm{Hf}}$ and $\varepsilon_{\mathrm{Nd}}$ values in a granitoid body. We suggest that the Hfisotopic variation in the Vaasa complex samples is caused by disequilibrium melting, and that the source of the Vaasa complex diatexites are the Evijärvi belt metasedimentary rocks with very minor juvenile components at most.

\subsection{Major and trace element Geochemistry}

The granitoid rocks of the Vaasa area are mostly peraluminous. However, meta- luminous compositions are not rare in the Vaasa migmatite complex, especially in the low- $\mathrm{SiO}_{2}(64-$ 67 wt.\%) granodiorites and the sparse tonalitic rocks described by Sipilä et al. (2008). Sample A2176 has an ASI-value of 1.05 (Fig. 6) and $\mathrm{Na}_{2} \mathrm{O}$ contents of $4.4 \%$, which define the sample as an I-type granitoid. However, it is questionable whether this classification is applicable for the Vaasa migmatite complex or not, as the samples are most likely of a similar origin and the values only show minor variation.

Paleosome inclusions are scarce in the Vöyritype, which suggests that these granitoids are the result of even more extensive anatexis caused by differences in source material or in the conditions of partial melting. However, the elemental analyses of Sipilä et al. (2008) imply that the Vöyri granitoids are notably more felsic and have higher $\mathrm{FeO} /$ $\mathrm{MgO}$ values and concentrations of $\mathrm{K}_{2} \mathrm{O}$ than the surrounding Vaasa type rocks. Therefore, on the basis of their chemical compositions, the Vöyri rocks could represent either minimum-melt granites (cf. the minimum-melt compositions from McRae and Nesbitt, 1980) or simply granites that formed by the melting of Vaasa type diatexites. Sample A2180 belongs to the Vöyri-type based on the absence of

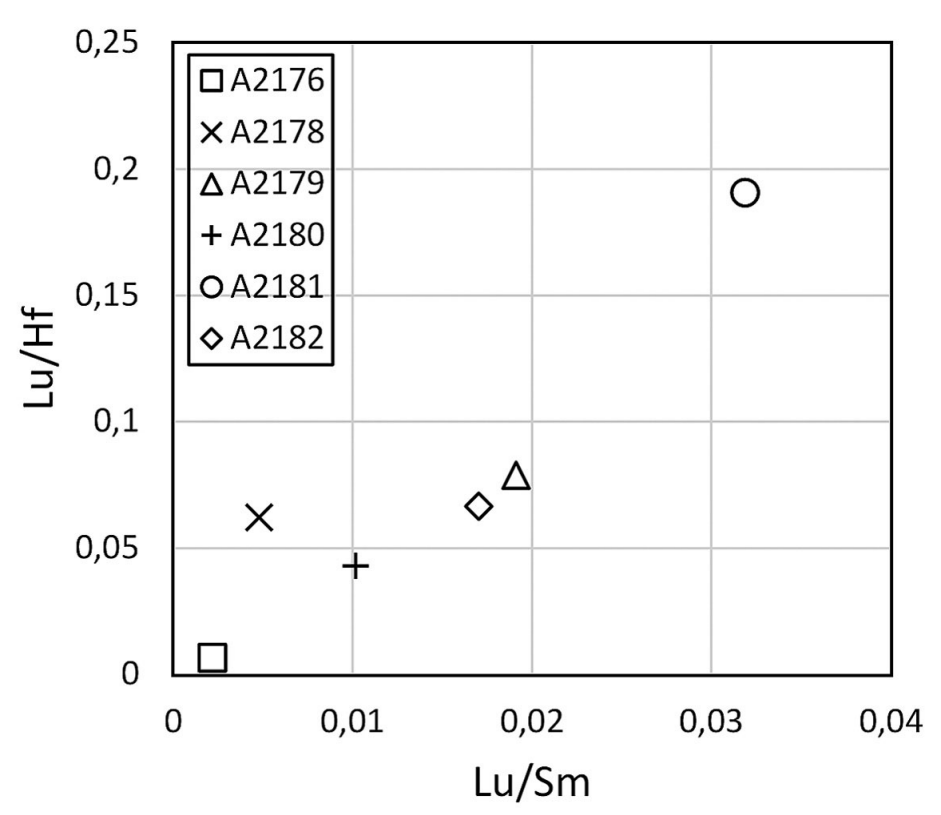

Fig. 8. A Lu/Hf vs. Lu/Sm diagram of the Vaasa area samples. 
metasedimentary relicts, even though it has $\mathrm{SiO}_{2}$ contents of only $-69 \%$ in contrast to consistent values of $\geq 70 \%$ reported by Sipilä et al. (2008).

The high amount of garnet at the southern Vaasa migmatite complex suggests that biotite dehydration melting has been a significant mechanism in the formation of the complex (cf. Le Breton and Thompson, 1988). Fig. 8 shows that samples A2176 and A2180 have low Lu/Hf and Lu/Sm values compared to the Evijärvi mica schist sample A2182. Because HREE are compatible with the structure of garnet, Lu contents of a melt can be mostly controlled by residual garnet (e.g., Vervoort et al., 2000). The garnet-free samples could represent the liquid that separated from garnet-rich cumulates, such as those represented by samples A2179 and A2181. Although sample A2178 has a low Lu/Hf value, which indicates Lu-depletion, its $\mathrm{Lu} / \mathrm{Sm}$ value is the same than that of sample A2182. Moreover, although garnet is not present in the sample, it is not completely absent in the sample site (A. Kotilainen, pers. comm., 2013).

\section{Conclusions}

The culmination of the Svecofennian orogeny in western Finland at 1.90-1.87 Ga resulted in an anatectic event in the Evijärvi belt area. The anatexis gave birth to an extensive migmatite body where the bedrock is dominated by diatexites with leucosomes of S-type granitoid affinity. The $\mathrm{Nd}$ isotopic data presented in this study complement the research of, e.g., Sipilä et al. (2008) and Mäkitie (2001), and promote our hypothesis of the formation of the Vaasa migmatite complex by anatexis of Evijärvi belt rocks. The average $\varepsilon_{\mathrm{Hf}}(\mathrm{t})$ values of the Vaasa complex sample zircon largely correspond with the initial $\varepsilon_{\mathrm{Nd}}$ values. The observed variation in the average $\varepsilon_{\mathrm{Hf}}(\mathrm{t})$ values is likely caused by disequilibrium melting of zircon and permits no further conclusions. Furthermore, the 2.02-1.92 Ga and c. $2.7 \mathrm{Ga}$ detrital zircon cores present in some samples represent similar zircon populations to those of the Evijärvi belt sample and to the literature values for detrital zircon ages in Svecofennian metasedimentary rocks. Geochemical features, such as
Lu depletion, for some of the samples in this study indicate that their parental magmas were formed in the presence of residual garnet.

\section{Acknowledgements}

This research was funded by K.H. Renlund's Stiftelse and M. Kurhila's work by the Academy of Finland as parts of the "Three dimensional evolution of the middle crust in Central Fennoscandia" -project led by Annakaisa Korja. We are grateful to Mirja Saarinen, Leena Järvinen, Arto Pulkkinen and Hugh O'Brien for their invaluable help during sample preparation and analyses. We also wish to thank Tapani Rämö and the reviewers Stefan Claesson and Jussi Heinonen for their constructive reviews.

\section{Supplementary data}

Electronic Appendices A and B for this article are available via Bulletin of the Geological Society of Finland web page.

\section{References}

Andersen, T., Griffin, W.L. \& Pearson, N., 2002. Crustal Evolution in the Sw Part of the Baltic Shield: the Hf Isotope Evidence. Journal of Petrology 43, 1725-1747.

Bouvier, A., Vervoort, J.D. \& Patchett, P.J., 2008. The Lu-Hf and $\mathrm{Sm}-\mathrm{Nd}$ isotopic composition of CHUR: Constraints from unequilibrated chondrites and implications for the bulk composition of terrestrial planets. Earth and Planetary Science Letters, 273, 48-57.

Brown, M., 2008. Granites, migmatites and residual granulites: Relationships and processes. In: Sawyer, E.W., Brown, M. (Eds.), Mineralogical Association of Canada Short Course 38, Quebec City, Quebec, pp. 97-144.

Chu, N., Taylor, R.N., Chavagnac, V., Nesbitt, R.W., Boella, R.M., Milton, J.A., German, C.R., Bayon, G. \& Burton, $\mathrm{K}$., 2002. Hf isotope ratio analysis using multi-collector inductively coupled plasma mass spectrometry: an evaluation of isobaric interference corrections. Journal of Analytical Atomic Spectrometry 17, 1567-1574.

Claesson, S., Huhma, H., Kinny, P.D. \& Williams, I.S., 1993. Svecofennian detrital zircon ages - implications for the Precambrian evolution of the Baltic Shield. Precambrian Research 64, 109-130.

Cox, K.G., Bell, J.D. \& Pankhurst, R.J., 1979. The Interpretation of Igneous Rocks. Allen and Unwin, London. $450 \mathrm{p}$.

DePaolo, D.J., 1981. A Neodymium and Strontium Isotopic Study of the Mesozoic Calc-Alkaline Granitic Batholiths of the Sierra Nevada and Peninsular Ranges, California. Journal of Geophysical Research 86, 10470-10488. 
Fedo, C.M., Sircombe, K.N. \& Rainbird, R.H., 2003. Detrital Zircon Analysis of the Sedimentary Record. Reviews in Mineralogy and Geochemistry 53, 277-303.

Gerdes A. \& Zeh A., 2006. Combined U-Pb and Hf isotope La-(MC-)ICPMS analyses of detrital zircons: Comparison with SHRIMP and new constraints for the provenance and age of an Armorican metasediment in Central Germany. Earth and Planetary Science Letters 249, 47 61.

Hietanen, A., 1975. Generation of potassium-poor magmas in the northern Sierra Nevada and the Svecofennian of Finland. Journal of Research of the US Geological Survey 3, 631-643.

Huhma, H., 1986. Sm-Nd, U-Pb and $\mathrm{Pb}-\mathrm{Pb}$ isotopic evidence for the origin of the Early Proterozoic Svecocarelian crust in Finland. The Geological Survey of Finland Bulletin 337.

Huhma, H., 1987. Provenance of early Proterozoic and Archaean metasediments in Finland: a Sm-Nd isotopic study. Precambrian Research 35, 127-143.

Huhma, H., Claesson, S., Kinny, P.D. \& Williams, I.S., 1991. The growth of early proterozoic crust: New evidence from Svecofennian detrital zircons. Terra Nova 3, 175-179.

Huhma, H., O’Brien, H., Lahaye, Y. \& Mänttäri, I., 2011. Isotope geology and Fennoscandian lithosphere evolution. Geological Survey of Finland Special Paper 49, 35-48.

Huhma, H., Mänttäri, I., Peltonen, P., Kontinen, A., Halkoaho, T., Hanski, E., Hokkanen, T., Hölttä, P., Juopperi, H., Konnunaho, J., Lahaye, Y., Luukkonen. E., Pietikäinen. K., Pulkkinen, A., Sorjonen Ward, P., Vaasjoki, M. \& Whitehouse, M., 2012a. The age of the Archaean greenstone belts in Finland. Geological Survey of Finland, Special Paper 54, 74-175.

Huhma, H., Kontinen, A., Mikkola, P., Halkoaho, T., Hokkanen, T., Hölttä, P., Juopperi, H., Konnunaho, J., Luukkonen, E., Mutanen, T., Peltonen, P., Pietikäinen, K. \& Pulkkinen, A. 2012b. Nd isotopic evidence for Archaean crustal growth in Finland. In: Hölttä P. (Ed.), The Archaean of the Karelia Province in Finland. Geological Survey of Finland, Special Paper 54, 176213.

Jacobsen, S.B. \& Wasserburg, G.J., 1980. Sm-Nd isotopic evolution of chondrites. Earth and Planetary Science Letters 50, 139-155.

Kähkönen, Y., 2005. Svecofennian supracrustal rocks. In: Lehtinen, M., Nurmi, P. A., Rämö, O. T. (Eds.), Precambrian Geology of Finland. Key to the Evolution of the Fennoscandian Shield. Elsevier B.V., Amsterdam, pp. 343-406.

Korja, A. \& Heikkinen, P., 2005. The accretionary Svecofennian orogen - insight from the BABEL profiles. Precambrian Research 136, 241-268.

Korsman, K., Koistinen, T., Kohonen, J., Wennerström, M., Ekdalh, E., Honkamo, M., Idman, H. \& Pekkala, Y. (Eds.), 1997. Bedrock map of Finland 1:1000000. Geological Survey of Finland, Espoo, Finland.

Kouvo, O. \& Tilton, G. 1966. Mineral ages from the Finnish
Precambrian. Journal of Geology 74, 421-442.

Lahtinen, R. \& Huhma, H., 1997. Isotopic and geochemical constraints on the evolution of the 1.93-1.79 Ga Svecofennian crust and mantle in Finland. Precambrian Research 82, 13-34.

Lahtinen, R., Huhma, H. \& Kousa, J., 2002. Contrasting source components of the Paleoproterozoic Svecofennian metasediments: Detrital zircon U-Pb, Sm-Nd and geochemical data. Precambrian Research 116, 81-109.

Lahtinen, R., Korja, A. \& Nironen, M., 2005. Paleoproterozoic tectonic evolution. In: Lehtinen, M., Nurmi, P.A., Rämö, O.T. (Eds.), Precambrian Geology of Finland - Key to the Evolution of the Fennoscandian Shield. Elsevier B.V., Amsterdam, pp. 481-532.

Lahtinen, R., Huhma, H., Kähkönen, Y. \& Mänttäri, I., 2009. Paleoproterozoic sediment recycling during multiphase orogenic evolution in Fennoscandia, the Tampere and Pirkanmaa belts, Finland. Precambrian Research 174, 310-336.

Le Breton, N. \& Thompson, A.B., 1988. Fluid-absent (dehydration) melting of biotite in metapelites in the early stages of crustal anatexis. Contributions to Mineralogy and Petrology 99, 226-237.

Ludwig, K.R., 2008. User's Manual for Isoplot 3.6 - A Geochronological Toolkit for Microsoft Excel. Berkeley Geochronology Center Special Publication No. 4.

MacRae, N.D. \& Nesbitt, H.W., 1980. Partial Melting of Common Metasedimentary Rocks: A Mass Balance Approach. Contributions to Mineralogy and Petrology 75, 21-26.

McDonough, W.F. \& Sun, S.-S., 1995. Composition of the Earth. Chemical Geology 120, 223-253.

Morel M.L.A., Nebel O., Nebel-Jacobsen Y.J., Miller J.S. \& Vroon P.Z., 2008. Hafnium isotope characterization of the GJ-1 zircon reference material by solution and laserablation MC-ICPMS. Chemical Geology 255, 231-235.

Mäkitie, H., Kärkkäinen, N., Lahti, S.I. \& Lehtonen, M.I., 1999. Chemical and modal compositions of granitoids in three different geological units, South-Pohjanmaa, western Finland. Geological Survey of Finland Special Paper 27, 7-19.

Mäkitie, H., 2001. Eastern margin of the Vaasa migmatite complex, Kauhava, western Finland: Preliminary petrography and geochemistry of the diatexites. The Geological Society of Finland Bulletin 73.

Nironen, M., 1997. The Svecofennian Orogen: a tectonic model. Precambrian Research 86, 21-44.

Nironen, M., 2005. Proterozoic orogenic granitoid rocks. In: Lehtinen, M., Nurmi, P.A., Rämö, O.T. (Eds.), Precambrian Geology of Finland - Key to the Evolution of the Fennoscandian Shield. Elsevier B.V., Amsterdam, pp. 443-480.

Patchett P. J., Kouvo O., Hedge C. E. \& Tatsumoto M., 1981. Evolution of continental crust and mantle heterogeneity: 
Evidence from Hf isotopes. Contributions to Mineralogy and Petrology 78, 279-297.

Peltonen, P., 2005. Svecofennian mafic-ultramafic intrusions. In: Lehtinen, M., Nurmi, P.A., Rämö, O.T. (Eds.), Precambrian Geology of Finland - Key to the Evolution of the Fennoscandian Shield. Elsevier B.V., Amsterdam, pp. 407-442.

Rosa, D.R.N., Finch, A.A., Andersen, T. \& Inverno, C.M.C., 2009. U-Pb geochronology and $\mathrm{Hf}$ isotope ratios of magmatic zircons from the Iberian Pyrite Belt. Mineralogy and Petrology 95, 47-69.

Scherer, E.E., Münker, C. \& Mezger, K., 2001. Calibration of the Lutetium-Hafnium Clock. Science 293, 683-687.

Sipilä, P., Kujala, H. \& Torssonen, M., 2008. Pre-Quarternary rocks of the Oravainen-Lapua-Alahärmä area. Geological Survey of Finland. Report of Investigation 170.

Stacey, J.S. \& Kramers, J.D., 1975. Approximation of terrestrial lead isotope evolution by a two stage model. Earth and
Planetary Science Letters 26, 207-221.

Tang, M., Wang, X-L., Shu, X-J., Wang, D., Yang, T. \& Gopon, P., 2014. Hafnium isotopic heterogeneity in zircons from granitic rocks: Geochemical evaluation and modeling of "zircon effect" in crustal anatexis. Earth and Planetary Science Letters 389, 188-199.

Vaasjoki, M., Huhma, H., Lahtinen, R. \& Vestin, J., 2003. Sources of Svecofennian granitoids in the light of ion probe $\mathrm{U}-\mathrm{Pb}$ measurements on their zircons. Precambrian Research 121, 251-262.

Vervoort, J.D., Patchett, P.J., Blichert-Toft, J. \& Albarède, F., 1999. Relationships between Lu-Hf and Sm-Nd isotopic systems in the global sedimentary system. Earth and Planetary Science Letters 168, 79-99.

Vervoort, J.D., Patchett, P.J., Albarède, F., Blichert-Toft, J., Rudnick, R. \& Downes, H., 2000. Hf-Nd isotopic evolution of the lower crust. Earth and Planetary Science Letters 181, 115-129. 